\title{
Feminist Cinema as Counter Cinema: Is Feminist Cinema Counter Cinema?
}

\author{
Hasan Gürkan, İstanbul Arel University, Turkey \\ Rengin Ozan, İstanbul University, Turkey
}

\begin{abstract}
The article of Peter Wollen "Godard and Counter Cinema: Vent D'est" is considered as the beginning of counter cinema. In 1979, “Women's Cinema As Counter Cinema” which was written by Claire Johnston and the article of Laura Mulvey "Visual Pleasure and Narrative Cinema" are accepted as the first theoretical studies of feminist cinema. Johnston, in her article, states that feminist cinema may be counter cinema and may be an alternative language against Hollywood movies in terms of production and content. When counter cinema, which has been produced with a different narrative and a different ideology against Hollywood (the dominant cinema), is analyzed with the seven sins of Wollen, how feminist cinema is counter cinema is the question of this study with the feminist movies. It is possible to say that feminist cinema shows counter-wiev in terms of ideological and the representation of woman against the dominant cinema. However, when the movies are considered in terms of narrative, it is wrong to consider as counter cinema of Wollen.
\end{abstract}

Keywords: Feminist cinema, counter cinema, Peter Wollen, Claire Johnston, Laura Mulvey 


\section{Introduction}

The development of feminist film theory was influenced by second wave feminism and the development of women's studies within the academy. Feminist scholars began taking cues from the new theories arising from these movements to analyzing film. Initial attempts in the United States in the early 1970s were generally based on sociological theory and focused on the function of women characters in particular film narratives or genres and of stereotypes as a reflection of a society's view of women. Works such as Marjorie Rosen's Popcorn Venus: Women, Movies, and the American Dream (1973) and Molly Haskell's From Reverence to Rape: The Treatment of Women in Movies (1974) analyze how the women portrayed in film related to the broader historical context, the stereotypes depicted, the extent to which the women were shown as active or passive, and the amount of screen time given to women (Erens, 1990: 16). The Imaginary Signifier, "Identification, Mirror," Christian Metz argues that viewing film is only possible through scopophilia ${ }^{1}$, which is best exemplified in silent film (Braudy and Cohen, 2004: 827).

In considering the way that films are put together, many feminist film critics have pointed to the "male gaze" that predominates in classical Hollywood filmmaking. Boetticher summarises the view thus: "What counts is what the heroine provokes, or rather what she represents. She is the one, or rather the love or fear she inspires in the hero, or else the concern he feels for her, who makes him act the way he does. In herself the woman has not the slightest importance" (Erens, 1990: 16). Laura Mulvey's influential essay "Visual Pleasure and Narrative Cinema" (written in 1973 and published in 1975) expands on this conception of the passive role of women in cinema to argue that film provides visual pleasure through scopophilia, and identification with the on-screen male actor ${ }^{2}$. With feminist cinema and its oppositional, many film theories says that feminist cinema is counter cinema. However, when Peter Wollen's 7 sins are put into use, how feminist cinema is counter cinema in terms of narrative.

\section{What is Feminism?}

Feminism is a term frequently used in daily life, although there is debate about what it means. Some of them, such as the struggle for feminism or women's war is not wrong, but

\footnotetext{
${ }^{1}$ Please look at page 6.

${ }^{2}$ Mulveys' opinions will be mentioned in further (page 6).
} 
incomplete descriptions of feminist thought by some negative and pejorative meaning when installed state is a myth. Patriarchal social structure of this situation, there are many reasons, such as male-dominated discourse and dualistic thinking (Alkan, 1998:1).

On the other hand, accepted meaning or definition of feminism as theoretically is difficult to describe. The problems of women in different processes and environments, socioeconomic and cultural position and different political objectives are the basic reason to describe easily. Thus, numerous feminist movement, approach and action have been developed. This case causes as pieces structure of feminism at first, on the other hand it provides feminist theory to understanding, action, and act circumstances. Although there is not a common definition of feminism, as Mitchell points out, "it is a initiated struggle that women's creating solidarity with each other against the norms and values of male-dominated world, sexist policies" (Mitchel, 1995: 6) will help to draw a general framework to define the form of. Feminism aims to question the concept of the male-dominated world, at the same time, it is also intended to avoid some difficulties women face in life.

Feminism is a theory which rises over women unfairly because of social inequality (MacKinnon, 2003: 57). In this context, the main problematic of feminist thought, the social differences between men and women, its causes and consequences has been established. This difference has a basis in fact going back to early days of the history of thought (Akal, 2003: 250).

Feminist Film Theory and Feminist Cinema In the 1979 essay "Women's cinema as countercinema" Johnston argues that a feminist cinema should be a counter cinema and has the potential to posit an alternative to Hollywood films both in rejecting its content and means of production. Others have argued that in embracing the strategies of the avant-garde the films actually lose some of their political impact rather than posing an alternative they lose there audience (Keenan, www.prezi.com/ga2zvt81drap/cinema-and-society-counter-cinema/, Access Time: 15 December 2012). Laura Mulvey argued in her 1975 essay "Visual Pleasure and Narrative Cinema" that the gaze that Hollywood cinema catered for was a male gaze. She argued that mainstream cinema generally places a male character at the centre of the narrative which the audience is assumed to relate to whilst woman are positioned for visual impact and erotic pleasure. Furthermore she argued that female characters who did not adhere to the 
female stereotype were punished as a threat to both the characters on screen and the male spectator Towards a "counter cinema" (Keenan, www.prezi.com/ga2zvt81drap/cinema-andsociety-countercinema/, Access Time: 15 December 2012).

Counter-cinema is the rough grouping of films, film makers, and institutions which attempt to work against the formalist and ideological domination of Hollywood cinema. This is quite a broad definition. It effectively means that counter cinema includes films that do not follow linear plots, have stereotyped characters or are hyper-violent. In fact, one could say that counter cinema does not strictly exist as one concept. Some research suggests that it started with feminist film. Feminist film theoretician, Claire Johnston, said women's cinema could function as "counter cinema". Through consciousness of the means of production and opposition of sexist ideologies, films made by women have the potential to posit an alternative to traditional Hollywood films (Anderson, www.screenforum.blogspot.com/2011/06/counter-cinema.html, Acces Time: 15 December 2012).

Alongside the expansion of feminism and the women's movement alternative and avantgarde-cinema was flourishing. Independet cinema could at its simplest, be divided into two forms: documentary and avant-garde. British film has a strong documentary tradition, which was to some extent socialist-influenced, and feminist film intially saw documentary as a way of presenting the "truth" about the lives of women. During the 1960s American, avantgarde film-makers produced many innovative and controversial films, some of the most well known being 'gay' and 'camp' films that challenged traditional stereotypes of gender roles such as Andy Warhol's Lonesome Cowboys (1968) and Kenneth Anger's Scorpio Rising (1965). Also in Europe, avant-garde film had been taken up by a number of filmmakers, Jean-Luc Godard and François Truffaut being its most famous exponents. Although gender roles in European films tended to be stereotypical, some feminist film-makers saw the potential of avant-garde film as a means of breaking away from the constraints of traditional cinema (Nelmes, 1996: 228).

Many feminist film-makers in the 1970s appropriated ideas from avant-garde art cinema and applied them to discuss questions that were of concern to the women's movement, such as representation. The avant-garde had always been male-dominated and narrow in its 
representations of women. But the avant-garde's political/anarchist basis gave an alternative from to the traditional use of realism in both fiction and documentary film. This influence was most profound in film-makers like Laura Mulvey's and Sally Potter's films (Nelmes, 1996: 230).

Claire Johnston's Women's Cinema as a Counter Cinema (1973) is one of the earliest articles on feminist film theory and practice. Johnston shows how women have been stereotyped in film since the days of the silent cinema, and argues for a cinema that challenges such narrow conventions but which will also be entertaining. In mainstream cinema, woman is seen as an extension of a male vision and Johnston criticizes the narrow role she is given in film: 'It is probably true to say that despite the enormous emphasis placed on woman as spectacle in the cinema, woman as woman is largely absent' (Nelmes, 1996: 230). The work of two female Hollywood directors, Dorothy Arzner and Ida Lupino, is considered by Johnston, who suggests that their films partially subvert the patriarchal viewpoint. An understanding of how these films work could be important for feminist film practice in breaking through and challenging the ruling ideology. She argues for a woman's cinema that will work collectively in groups with no hierarchical structure but also more conventionally, using film as a political tool and an entertainment. The importance of developing a film practice that questions and challenges mainstream dominant cinema movement which will have links with avant-garde and left-wing film (Nelmes, 1996: 230).

Johnston emphasizes the importance of developing cinematic practice which is opposed to the basis of the dominant cinema and its male-dominated. She called this "counter cinema" which will be related to avant-garde and left-wing. Johnston tries to explain how the woman's ideological image is settlement. According to Barthes (1991: 25) indicator of "woman" is analyzed as a structure, a password or a tradition. This indicator represents the ideological meaning of "woman" for man. When women associate with each other do not have a meaning (1992: 25): women are presented as "non-male" negatively. "Woman as woman" is not existing inside the movie. The difference of here, rather than addressing the reality of the cinema as a phenomenon that reflects the reality of the cinema as a case dealing with a particular ideological point of view, is to configure. Classic cinema never shows the tools of the production. The narrator of the classic cinema presents the artificial "woman" image as natura, real and attractive. This is the eyewash of classical cinema. 
According to Mulvey (2009) "alternative cinema provides a space for a cinema to be born which is radical in both a political and an aesthetic sense and challenges the basic assumptions of the mainstream film.'In order to understand what Mulvey (2009: 717) has in mind when she refers to an alternative cinema it is important to understand the role of classical cinema in supporting the phallocentric/patriarchal role of the male gaze. Mulvey emphasizes, among cinema's many possible pleasures, the importance of scopophilia in the forms of voyeurism and narcissism. Classical cinema encourages these pleasures through formal and narrative structures that emphasize an active/male and passive/female role in film. As regards the process of viewing a film these structures establish a tension between "the spectator in direct scopophilic contact with the female form displayed for his enjoyment (connoting male phantasy) and that of the spectator fascinated with the image of his like set in an illusion of natural space, and through him gaining control and possession of the woman within the diegesis.” Thus, “[g]oing far beyond highlighting a woman's to-be-looked-at-ness, cinema builds the way she is to be looked at into the spectacle itself" (2009: 721). This gaze, or look, structured by the filmic event, has three different expressions; "that of the camera as it records the profilmic event, that of the audience as it watches the final product, and that of the characters at each other within the screen illusion" (Mulvey, 2009: 721). Any film belonging to Mulvey's alternative cinema must work to reject each of these looks in its formal and narrative construction.

\section{Discussing Feminist Cinema as Counter Cinema and Deciding Counter Cinema}

In order to be able to define "counter cinema", we first need to answer of the question "Against What?". The short and clear answer of this question is defined by the "main stream" of Hollywood and its imitators. Counter movies are separated from classic movies in terms of ideological.Wollen says that Godard has developed a counter-cinema whose values are counterposed to those of orthodox cinema. The approach of Wollen is to take seven of the values of old cinema, Hollywood-Mosfilm as Godard would put it, and contrast with their counterparts and contraries (Wollen, 1972: 120): ${ }^{3}$

\footnotetext{
${ }^{3}$ This part of the article had been developed from another article of the same authors, namely "The Transformation of Counter Cinema on Hollywood in the Butterfly Effect".
} 


\begin{tabular}{|l|l|}
\hline HOLLYWOOD NARRATIVE & COUNTER CINEMA NARRATIVE \\
\hline Narrative Transivity & Narrative Intransivity \\
\hline Identification & Estrangement \\
\hline Transparency & Foregrounding \\
\hline Single diegesis & Multiple diegesis \\
\hline Closure & Aperture \\
\hline Pleasure & Un-pleasure \\
\hline Fiction & Reality \\
\hline
\end{tabular}

Wollen (1972: 120-129) states the differences between Hollywood narrative and counter cinema narrative as below:

Narrative Transivity v. Narrative Intransivity: (One thing following another v. gaps and interruptions, episodic construction, undigested digression.) By narrative transivity, Wollen means a sequence of events in which each unit (each function that changes the course of the narrative) follows the one preceding it according to a chain of causation. In the Hollywood cinema, this chain is usually psychological and is made up, roughly speaking, of a series of coherent motivations. The beginning of the film stars with establishment, which set sup the basic dramatic situation. A kind of chain reaction then follows, until at the end a new equilibrium is restored. However, in the narration of counter cinema, there are separate areas which interruption of the story. Irrelevant events supplant each other as in the real life.

Identification v. Estrangement: (Empathy, emotional involvement with a character v. direct address, multiple and divided characters, commentary) Identification is a well-known mechanism though, of course, in the cinema there are various special features which mark cinematic identification off as a distinct phenomenon. First of all, there is the possibility of double identification with the star and/or with the character. Secondly, the identification can only take place in a situation of suspended belief. Third, there are spatial and temporal limits either to the identification or, at any rate, to the presence of the imago. In the narrative form, counter cinema breaks the identification and provides estrangement. Such as the actors speak to the audiences directly, real people in fiction, audio tape destroy the identification.

Transparency v. Foregrounding: ("Language wants to be overlooked" --- Siertsema v. making the mechanics of the film/text visible and explicit) Traditional cinema is in the direct 
line of descent from the Renaissance discovery of perspective and reformulation of the art of painting, expressed most clearly by Alberti, as providing a window on the world. The camera is simply the technological means toward achieving a perfect perspective construction. After the Renaissance the painting ceased to be a text which could be "read", as the iconographic imagery and ideographic space of pre- Renaissance painting were gradually rejected and replaced by the concept of pure representation. In the narration of Hollywood, the audience should forget a movie. In the narration, counter cinema features the attention of the audience, and makes the audience's pay attention to the camera. Technical team and technical tools in the scene make the audience perceive and comprend a movie they are watching.

Single Diegesis v. Multiple Diegesis: (A unitary homogenous world v. heterogeneous worlds. Rupture between different codes and different channels) In Hollywood films, everything shown belongs to the same world, and complex articulations within that world such as flashbacks - are carefully signaled and located. The dominant aesthetic is a kind of liberalized classicism. The rigid constraints of the dramatic unities have been relaxed, but mainly because they were over - strict and limiting, whereas the basic principle remains unshaken. Time and space must follow a consistent order. Traditionally, only one form of multiple diegesis is allowed - the play within a play - whereby the second, discontionus diegetic space is embedded or bracketed within the first. The narration of Hollywood presentsa consistent world. Everything in film belongs to this world. The narration of counter cinema destroys this world. It presents a heterogeneous world against to a homogeneous world.

Closure v. Aperture: (A self-contained object, harmonized within its own bounds v. openendedness, overspill, intertextually - allusion, quotation, and parody) Wollen has often been pointed out that in recent years, the cinema has become self-conscious in contrast to the innocent days of Hollywood. Hoewer, in itself, self-consciousness is quite compatible with closure. Hollywood movies fold up. The conflicts in the plot are solved. The narration of counter cinema ends up with the open-ended. Ambiguity at the end of the film is remained not to be solved.

Pleasure v. Unpleasure: (Entertainment, aiming to satisfy the spectator v. provocation, aiming to dissatisfy and hence change the spectator) The attack on entertainment cinema is 
part of a broader attack on whole of consumer society. Cinema is conceived of as a drug that lulls and mollifies the militancy of the masses, by bribing them with pleasurable dreams, thus distracting them from the stern tasks which are their true destinity. The narration of Hollywood entertains the audiences and makes them have good time. The narration of counter cinema aims to provoke and have the attention of audience.

Fiction v. Reality: (Actors wearing make-up, acting a story v. real life, the breakdown of the representation, truth) Audience, in the narration of Hollywood, enters into fiction world that is created for oneself with the identification. In counter cinema, audience is in the real world because the identification is broken and audience is disturbance. Audience is unaware of watching a movie and even analyze the movie with the critical thinking.

The movies of counter cinema show the philosophy and the stand against to life of the director. The movies of counter cinema which focus on the roles and the relations of people, base on the ambiguity. The movies of counter cinema do not offer consistent plot as well as traditional cinema. The problems and troubles may be solved or unsolved in counter cinema. The main causal device to solve these problems is not hero. The coincidences or unexpected news as in the real life (Armes, 1976: 11). With these considerations in mind it is useful to consider the overlaps of Peter Wollen's counter-cinema with Mulvey's alternative cinema. As Wollen argues in Godard and Counter Cinema: Vent D'est, "Godard ... developed a countercinema whose values are counterposed to those of orthodox cinema." (1972: 120). Wollen goes on to argue that for every important value of traditional cinema, of which he lists seven, Godard creates and presents a contrary value. Thus Godard's films may offer us an example of a film that transcends the phallocentric/patriarchal order, as it is the cinematic values, according to Mulvey, which shape the viewer's pleasure (Mulvey, 2009: 713). However the terms may not be immediately interchangeable. As Wollen suggests, Godard; "is mistaken if he thinks that .... a countercinema can have an absolute existence. It can only exist in relation to the rest of the cinema." (1972: 121).

Thus, Godard's work can have no meaning without the traditional cinema from which it flees. This raises the question of whether this relative existence allows room for the promotion of the gaze in his work. It will be necessary to consider each expression of the look in cinema and whether Godard manages to reject each. That being said, it will prove fruitless to attempt to demonstrate that Godard's entire body of work rejects the structures of visual pleasure 
systematically. Mulvey has herself written extensively on Godard and her own conclusions often emphasize the contradictions and complexity in the representation of women in his work. The contradictions apparent within Godard's depiction of women, the contradiction between his use of the female form to signify sexuality and his rigorous questioning of the film form itself constitutes a statement of the confusions and difficulties surrounding images of woman. This lack of coherence is a productive spring-board as a starting-point for understanding how and why woman's image accumulates its particular meanings and also as a basis for further development, the construction of a cinema which challenges those meanings and assumptions (Mulvey, 1989: 62).Counter cinema wants the audiences to be "those who see", not "those who watch". The attitude of counter cinema is against to the tradition of re-creating. As it creates the reality, it breaks off from its own reality and tries to lock up in the borders of virtual (Babal \& Tiğl1, m.friendfeedmedia.com/0120f6359861f8921e001932bfd4df5ce1862ba9, Access Time:1 February 2013). Godard re-designed the editing as a part of mise an scene. Thus, editing is constituting mise an scene. As Brecht said that "Reality includes the showing how the things are, not reproducing reality" (Monaco, 2002: 389).

According to Bordwell, counter cinema is a realistic cinema and the two principles to prompt counter cinema, are reality and authorial expressivity. It shows real places such as in the movies of New Realism and NewWave, and interests in modern "alienation". Counter cinema, on the other hand, uses the reality with the complicated characters as psychological (1979: 57).Bordwell states that the reality of counter cinema is different from documentary cinema and based on psychological subjectivity. The notion of reality influences the temporal and the spatial structure of the movie (1979: 58- 59).

Analyzing estrangement in cinema, it is possible to say that the loneliness of modern person, disappearing the values, the distance with the nature, dissatisfaction and the condition of getting used. In counter cinema, the language stands in a radical place. The main element of the movie is estrangement and lack of communication almost in all of the movies of counter cinema. The characters rewind the movie according to the plot or the atmosphere; film advances can be done in the middle of the dialogue, the light can be used as strangely almost in all of the movies of counter cinema (Babal \& Tiğli, 
m.friendfeedmedia.com/0120f6359861f8921e001932bfd4df5ce1862ba9, Access Date: 1 February 2013).

The real thing that defines counter cinema with the estrangement is "unpleasure". The audience is distubed by the language and the elements of the movie. Counter cinema messes the tradition of Hollywood such as taking interest of audience, the identification of a character and not being aware of watching a movie. The reaction of the audience is appeared as unconscious unpleasure. As there is a half of violence on the stage, the movie shows that is not real to the audiences. That evidently makes a relaxation, but reminds what they watched before is a movie at the same time (Babal \& Tiğli, m.friendfeedmedia.com/0120f6359861f8921e001932bfd4df5ce1862ba9, Access Time: 1 February 2013). With all those information above, we tried to clarify what counter cinema is according to Peter Wollen. According to those information, we can say that feminist cinema is not a counter cinema for Wollen. As mentioned above, for Wollen, counter cinema is discussed as narrative, plot, estrangement, foregrounding, multiple diegesis, aperture, and reality, not fiction. But, these elements are not existing in a feminist movie. Now, we examine two feminist movies whether feminist cinema is really counter cinema, or not.For instance, when we think of the movie Thelma and Louise (dir.: Ridley Scott, 1991) is a film with feminist elements that fails to be a fully feminist film, for a variety of reasons. As it is defined, a feminist is a female character who does not need a man in order to succeed or function in the world, but can do so on her own. Thelma and Louise really takes on a feminist perspective as these two women leave behind the contraints of their daily lives in order to find adventure and freedom. The road in this film along with their convertable represents their ticket to freedom. As long as they are driving on the road they are getting away from and escaping all that ties them down back home, namey the men in their lives.

Both women are in unhappy relationships and depend on each other for the only good and solid relationship that they have in life. I think this film takes on a feminist perspective as the women gain authority throughout the film, unfortunately through the use of guns and violence, but nevertheless these women take charge and enter what normally on the screen is viewed only as male characteristics. They become confident, assertive, and fearless. This sharply contrats the other road films we have viewed in which men are telling the story and women are visual stimuli, or sexual objects the men merely meet along the way. 
The term feminism describes the utopian view of the equality between men and women in terms of what both genders are able/expected to do, in terms of personal characteristics, actions, and lifestyles. Feminism allows women to step outside their culturally created gender roles and perhaps take on a job or activity or lifestyle that is not traditionally female, and thus allows for the freedom of choice, which is what we think feminism is at the core, the power of choice and individuality free from gender norms and cultural expectations.

The relationship between Thelma And Louise has many of the qualities Tannen discussed in which she claims that women's friendships generally tend to be based on a more intimate sharing of personal details and problems than are men's friendships. More importantly, the fact that Thelma's character changed and developed to become more like Louise's, and Louise remained largely the same, implied the positive feminist message that women who express independence and assertiveness in relation to men (and to each other) is more desirable. In the film, each character exorcises feelings about men that they were repressing. Thelma throws off her yoke of dependence on her husband when she sleeps with the hitchhiker, J.D., and Louise vents long pent-up feelings of anger regarding her own rape when she shoots Harlan. In fact, Louise's action of shooting Harlan supports Wood's claim that "...the feelings that accompany rape and sexual assault ... endure far beyond the act itself". In all these ways, the friendship between Thelma and Louise contains both older and more recent views of gender expectations of American women, highlights the dynamics of a female friendship, and serves as a vehicle for them (and vicariously, the audience) to express anger toward various, and still common, damaging male behaviors such as treating women as sex objects, which can lead to rape, or as property, which is simply dehumanizing.

Thelma and Louise certainly go against cultural norms as they become violent and assertive women as the film progresses. However, much like the film "Woman on a Motorcycle" their freedom is put to a halt when at the end of the film they die. The film recognizes them as outlaws who must be punished, which is customary in American films, however it also indicates that they must be punished in someway for their deviant behavior and expressed the idea that the wild woman will not go unpunished, and in some ways counteracts the freedom and feminist ideals that the film was promoting all along. Had they survived, which perhaps they did, it would have indicated that these women, though nontraditional escaped the binds of their daily lives and societal norms and remained truly free. 
Table 1: Structure of Thelma and Louise

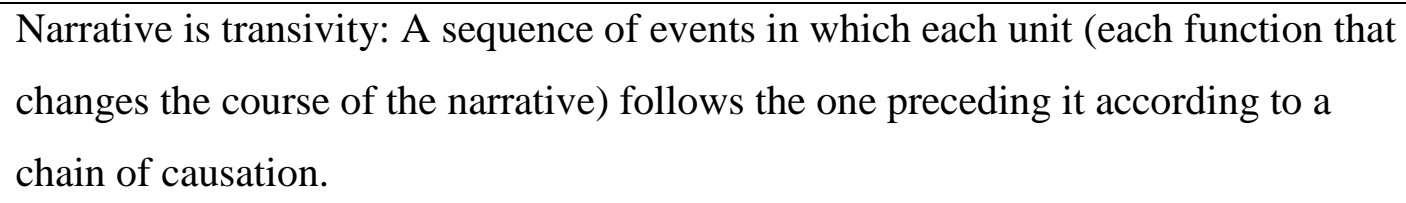

The film does not entertain the audiences. But, the film offers unpleasure because of its plot. The end of the film is not happy.

Audience, in the narration of the film, enters into fiction world that is created for oneself with the identification. Thus, the audiences can separate that is a film they are watching.

As the references above, and according to the ideas of Peter Wollen, we tried to summarize what counter cinema is exactly. When we see the movie Thelma and Louise, it is possible to say that the film is a feminist cinema, and according to Johnston and Mulvey, we can say that film is a feminist film and counter cinema. But its contrariness is coming from ideological, not narrative. The narrative of the movie is transivity. Another example of this study is the movie Erin Brockovich. In the movie of Erin Brockovich (dir.: Steven Soderbergh, 2000) tells a single mother's struggle. Erin has been raising three children while trying to maintain a successful career as a secretary. Reviewing this movie through a feminist perspective, we argue that it contains ideas from both the second and third waves of feminism. It focuses on the issues from the second wave of motherhood and careers, but it also touches on issues of sexual empowerment from the third wave. Erin is a strong, attractive woman in her early 40 's, trying to raise a family and gain a position of respect within the workplace, as well as try to discover her destiny. According to Roth, there are "many moral questions circulating in 
the USA at the turn of the millennium, such as whether mothers should work and whether corporations are corrupt" (2004: 55). This film touches on these questions and provides evidence that women can indeed be excellent mothers while maintaining a successful career. Women can have relationships without feeling as though they have to fall into the traditional male and female roles. And women can use their sexual features to gain necessities, acknowledgment and an advantage over men.

First, there are issues from the second wave presented in which Erin challenges the traditional roles of males and females in relationships. Although she has been married and divorced twice, she now knows that she has the capability to care for herself and her children without the support of a man. True, she lets her male neighbor who she is having a relationship with baby-sit her children while she is working, but she refuses his offer for her to quit working. He wanted to be the one to provide for her and the children, and while this is a noble act, Erin decides she has to prove to herself and everyone else that she can care for them on her own. Giving in to the "traditional" relationship, in which a man provides for a woman, Erin would be devaluing herself and her abilities. Another issue from the second wave of feminism that the film touches on is motherhood and the workforce. It was and still isa well-known fact that supposedly women cannot raise healthy and respectful children if she is working. "Erin must find the place to love them [her children] and still achieve her glory" (Rotha, 2004: 59).

The fight for the right to raise children and have a career has been around for decades, although it has not been as predominant as movement for sexual empowerment. But this movie reintroduces the audience the fact that equality within the workforce is far from being achieved and that we must continue fighting for what we deserve. Women have every right and all the capacity to instill good manners and morals within their children while making a profit within the workforce. Erin practically begs for the secretarial job, and in the beginning she struggles in preserving her relationships with her children, but in the end she learns to balance her career and the raising of her children. An issue raised in this film from the third wave of feminism is sexual empowerment. Erin Brockovich understands the power of her body and the effect that it has on men. She uses her sexual prowess to manipulate her male counterparts to complete tasks for her that they wouldn't usually complete. Towards the middle of the movie, Erin needs to acquire some records that a young man is not allowed to 
release to her. After she unbuttons her shirt to reveal more of her chest and hikes up her skirt to reveal more of her legs, the young man allows her to have all of the records she would like. Women hold a spell over men in which they can attain almost anything they desire through their sexual attributes. Erin acknowledges these advantages and makes them worth her while. "The film heralds her as a good mother, primarily for her traditional ability to empathize, her scrappy resilience, and her work ethic" (Rotha: 2004: 61).

The film Erin Brockovich brings forth ideas from both important feminist eras. It doesn't only center on sexual empowerment, a movement of the third and current wave of feminism, but it brings forward the issues of the second-wave as well. The film presents Erin as a strong-willed, determined woman, who will fight for her right to work while raising her children. This film is evidence that while it may seem that some issues have been forgotten in the modern fight for feminism, the issues never disappear.

\section{Table 2: Structure of Erin Brockovich}

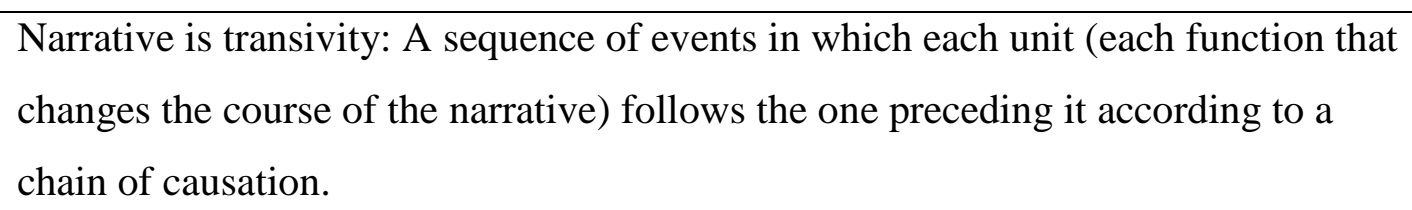


When we see the movie Erin Brockovich, it is possible to say that the film is a feministcinema. But its contrariness is coming from ideological, not narrative. The narrative of the movie is transivity. The cases are happening respectively as introduction-bodyconclusion. At the end of the move, Erin proves her success.

\section{Conclusion}

Claire Johnston put forth the idea that women's cinema can function as counter cinema. Through consciousness of the means of production and opposition of sexist ideologies, films made by women have the potential to posit an alternative to traditional Hollywood films. Many women filmmakers have integrated alternative forms and experimental techniques to encourage audiences to critique the seemingly transparent images on the screen and to question the manipulative techniques of filming and editing. In considering Mulvey's alternative cinema, especially in reference to counter cinema's films, we can say that it is essential to consider this dialectic6in order to resolve the difficulties in interpreting counter cinema's work as alternative. This point is similar to those made by Wollen and Mulvey, and Johnston in emphasizing the relational nature and complexity/confusion of counter cinema's work, respectively. If we consider the -prescriptive/descriptive dialectic in terms of feminist cinema then we can understand it as counter cinema. As such the difficulties that arise in interpreting feminist cinema as alternative cinema may be understood as necessary to a cinema that, though revolutionary, must draw on the reality of a patriarchal/phallocentric society in order to remain relevant.

Feminist cinema is a counter cinema, but its opposition is coming from its ideology and it is against to patriarchal system. But when counter cinema is analyzed with the ideas of Peter Wollen, there is a difference between "feminist cinema" and "counter cinema". Many feminist films are produced by taking the elements of classical cinema (the dominant cinema) except the position of woman/women. Women are presented more creative, active, independent and challenging. But in the narrative form of these movies, it is not possible to mention that they have the narrative form of counter cinema in full. As shown in the article with the examples of Ridley Scott's Thelma and Louise (1991) and Steven Soderbergh's ErinBrockovich (2000) are feminist film examples as ideological, but when they are compared to Wollen's counter cinema's elements, they are not seen as counter cinema. 


\section{References}

Akal, C. B. (1998) İktidarın Ü̧̧ Yüzü, Ankara: Dost Kitapevi Yay.

Alkan, A. (1998) Dünya'da ve Türkiye'de Kadın Hareketi ve Feminist Kuram (Ankara) (Yayınlanmamış Araştırma, A.Ü. Sos. Bil. Ens.)

Anderson, www.screenforum.blogspot.com/2011/06/counter-cinema.html, Acces Time: 15 December 2012).

Armes, R. (1976). The Ambiguous Image: Narrative Style in Modern European Cinema, USA: Indiana University Press.

Babal, G. \&Tı̆̆lı, Ö. Avrupa Sinemasında Yabancılaşma ve Gerçeklik ya da Rahatsız Etmenin Ikki Farklı Yolu, m.friendfeedmedia.com/0120f6359861f8921e001932bfd4df5ce1862ba9, Erişim Tarihi: 1 Şubat 2013)

Bordwell, D. (1979). "The Art Cinema as a Mode of Film Practice”, Film Criticism, say1: 4, s. $56-63$

Braudy and Cohen (2004). Film Theory and Criticism, Sixth Edition, Oxford University Press

Erens, P. (1990). “Introduction” Issues in Feminist Film Criticism. Patricia Erens, ed. Bloomington: Indiana University Press

Johnston, C. (1979). Women's Cinema as Counter Cinema. Sexual Stratagems: The World of Women in Film. Patricia Erens, ed. New York: Horizon Press

Keenan, www.prezi.com/ga2zvt81drap/cinema-and-society-counter-cinema/, Access Time: 15 December 2012).

Mackinnon, A. C. (2003) Feminist Bir Devlet Kuramına Doğru, çev: Türkan Yöney ve Sabir Yücesoy, İstanbul: Metis Yayınları

Mitchell, A. (1995) Feminizm, çev: Şirin Tekeli, Đstanbul: Đletişim Yay.

Monaco, J.(2002). Bir Film Nasıl Okunur? Sinema Dili, Tarihi ve Kuramı, çev. Ertan Y1lmaz, İstanbul: Oğlak Yayınları.

Mulvey, L.(2009). Visual Pleasure and Narrative Cinema, in Film Theory and Criticism: 7th Edition, ed. Leo Braudy and Marshall Cohen, New York: Oxford University Press Mulvey, L. (1989). Visual and Other Pleasures, Indianapolis: Indiana University Press Nelmes, J. (1996). Introduction to Film Studies, London: Routledge

Roth, E. (2004). “'I Just Want to Be a Decent Citizen:' Melodrama as Political Appeal in Erin Brockovich.” Feminist Media Studies, (4:1), 2004 Mar, 51-66. 
Wollen, P. (1972). Godard and Counter Cinema: Vent d'Est, Narrative, (inside) Apparatus, Ideology A Film Theory Reader, ed. by Philip Rosen, New York: Colombia University Press

\section{The movies inside the article}

Kenneth Anger's Scorpio Rising (1965)

Andy Warhol's Lonesome Cowboys (1968)

Ridley Scott's Thelma and Louise (1991)

Steven Soderbergh's Erin Brockovich (2000) 